\title{
TEACHER'S COMPETENCE AND DIFFICULTIES IN CONSTRUCTING HOTS INSTRUMENTS IN ECONOMICS SUBJECT
}

\author{
Dadang Dahlan*, Leni Permana, Mutiya Oktariani \\ Universitas Pendidikan Indonesia, Indonesia \\ *e-mail: dadangdahlan@upi.edu
}

\begin{abstract}
This research was motivated by the students' low high order thinking skill which was related to teachers' low competence in constructing high order thinking skills instrument. This study was intended to describe economics teachers' competence and difficulties in developing instruments to measure higher order thinking skills. The subjects of this study were 45 economics teachers and 270 students from 27 public high schools in Bandung. The study employed quantitative survey method with questionnaire and focus group discussion (FGD) as the instruments. The survey method was carried out to describe the teachers' competences and difficulties in constructing instruments. The results of the study indicated that the teacher's competence in constructing high order thinking skills instruments was low. The research findings showed that only $12 \%$ of the teacher-made questions can be categorized at the analyzing level to creating level, and $88 \%$ were categorized in remembering to applying level. This resulted in the teachers' obstacles in constructing higher order thinking skills instruments. The research findings signified that $80 \%$ of the teachers faced difficulties in constructing essay and multiple choices instruments.
\end{abstract}

\section{Keywords: Instrument, high order thinking skills, teachers' competence, Economics subject \\ KOMPETENSI GURU DAN KESULITAN MENGONSTRUKSI INSTRUMEN HOTS DALAM MATA PELAJARAN EKONOMI}

\begin{abstract}
Abstrak: Penelitian ini dilatarbelakangi oleh rendahnya kemampuan berpikir tingkat tinggi para siswa. Hal ini berkaitan dengan rendahnya kompetensi guru yang belum terbiasa mengonstruksi instrumen kemampuan berpikir tingkat tinggi. Tujuan penelitian adalah untuk mendeskripsikan kompetensi guru ekonomi dalam mengembangkan instrumen untuk mengukur kemampuan berpikir tingkat tinggi dan kesulitan guru ekonomi dalam mengonstruksi instrument kemampuan berpikir tingkat tinggi. Partisipan dalam penelitian adalah 45 guru ekonomi dan 270 siswa dari 27 Sekolah Menengah Atas Negeri di Kota Bandung. Metode penelitian yang digunakan adalah kuantitatif dalam bentuk survei dengan teknik pengumpulan data dokumentasi, kuesioner, dan fokus grup diskusi (FGD). Metode survei digunakan untuk mendeskripsikan kompetensi dan kesulitan guru dalam mengonstruksi instrumen. Hasil penelitian menunjukkan bahwa kompetensi guru dalam mengonstruksi instrumen berpikir tingkat tinggi tergolong rendah. Temuan penelitian menunjukkan hanya $12 \%$ dari soal buatan guru yang dapat dikategorikan pada jenjang analisis sampai kreasi, dan $88 \%$ termasuk dalam kategori mengingat sampai menerapkan. Hal ini mengakibatkan guru mengalami kesulitan dalam mengonstruksi instrumen berpikir tingkat tinggi. Temuan penelitian menunjukkan bahwa $80 \%$ guru mengalami kesulitan dalam mengonstruksi instrumen dalam bentuk esai maupun pilihan ganda.
\end{abstract}

\section{Kata Kunci: instrumen, kemampuan berpikir tingkat tinggi, kompetensi guru, mata pelajaran ekonomi}

\section{INTRODUCTION}

Instructional management is an activity to plan, implement, and assess teaching and learning process, and to develop classroom management (Danarwati, 2016; Nagro, Faser \& Hooks, 2018; Fahmi, Murniati, Nurliza \& Usman 2019). In this case, the main task of professional educators is to educate, teach, guide, direct, assess and evaluate students both in primary and secondary education levels (Depdiknas RI, 2014). As an evaluator, teacher must collect, analyze, interpret and make final assessment on the success of learning process according to the criteria to measure the process effectiveness 
aspect and the quality of the result.

Based on the 2013 curriculum, teachers need to assess skills which involve higher order thinking skills. Therefore, students have to be proficient in lower order thinking skills (LOTS) and higher order thinking skills (HOTS). It is essential for students to have high-order thinking skills since intelligent and skilled generation is recognized by the ability to have higher-order thinking in solving complex problems. This generation is able to compete in competitive globalization era.

Senk et al. (Thompson, 2008) in his article explained the characteristics of higher order thinking is being able to complete tasks without algorithm explanation before, provide justification, and multiple solutions towards the problems. Where justification or explanation is required, and where moving than one solution may be possible. In line with Senk, et al.'s oppinion, Vui (2001) stated that higher order thinking occurrence take places when new information is stored in memory, interrelated, rearranged, and extended to achieve a purpose or to find the potential answers in difficult situation. Hence, higher order thinking skills occur when people associate new information with the stored information in their memory and then relates it and / or rearranges and develops the information to achieve a goal or find solution to a problematic situation.

Based on data from the 2011 Trends in International Mathematics and Science (TIMSS) survey which measures higher order thinking skills, it can be inferred that Indonesian students' high order thinking skills are low. Indonesian students can only work on questions in the low category which are knowing or remembering level (Mullis, Martin, Foy, \& Arora (2012).

Based on World Bank report from a study by the International Association for the Evaluation of Educational Achievement (IEA) in Asia, Indonesian Fourth grade primary school student reading competence was in the lowest rank. The average reading test score of Indonesian students was 51.7 which indicated that Indonesian students could only comprehend $30 \%$ of the reading materials and were still facing difficulty in answering essay questions that required higher-order thinking skills. Indonesian students were accustomed to answer teacher-made questions in low cognitive level.
The low ability of Indonesian students in applying higher order thinking skills showed that the education quality in Indonesia still needs to be improved in many ways, including the improvement of teachers' competences. One of the teachers' competences that must be improved is in constructing questions to measure higherorder thinking skills.

The low quality of teacher-made questions can be seen from several indicators, such as invalid and unreliable questions, no blueprint, low linguistic aspect, and intended to measure low order thinking skills. Haynie (1992) stated that teachers lack test-development training, fail to do test analysis, do not establish reliability or validity of questions, do not utilize blueprint test, put all content in equal position, test below basic knowledge level, and construct test with grammatical and spelling errors.

In line with the result of a research conducted by Balitbang Ministry of National Education, (Winne, 1979; Biggs, 1996; Rosenshine, Meister \& Chapman, 1996) found out that most of the teacher-made tests had low quality questions since they had not fulfilled the compulsory steps in drafting multiple-choice questions.

Along with the development of curriculum in many countries, there were sufficient empirical studies conducted on higher-order thinking skills (HOTS) learning and assessment, including in Malaysia. Nagappan (2001) affirmed that learning based on higher-order thinking skills had already begun in the early 1990s. It is reflected in one of the higher education objectives in Malaysia which is reading to develop and enhance students' intellectual capacity with rational, critical and creative thinking.

Another study conducted by Nesbitt-Hawes (2005) in Australia was inspired by the fact that the world changes rapidly and students were expected to develop their higher-order thinking skills to complete their tasks in every subject. Moreover, they were also expected to use various higher-order thinking skills in every subject. For example, in a Science class in Queensland, higher-order thinking skills are assessed from the complex logical thinking and scientific skills. This study was conducted to know how well the Science class students employed higher-order thinking skills to finish their complex science tasks using computer simulation. In addition, 
this study was a quantitative and qualitative case study. The result of the study implied that simulation facilitate students to think about the material and debate on the issues profoundly. Moreover, student's competence in arguing an issue was increased, students felt satisfied with the learning outcomes, students study Science autonomously, and they discover the knowledge required.

In Indonesia, Astudy conducted by Istiyono, Mardapi, \& Suparno (2014) was intended to develop high school students' Physics' higherorder thinking skills (PhysTHOTS) instrument and to obtain the characteristic of PhysTHOTS. The blueprint of the instrument was constructed based on aspects and sub-aspects of higher-order thinking skills which then utilized to develop question items. The instrument consisted of two test kits which had 26 items in each. The all items were validated by experts in measuring and physics education, and physics practitioner. $\mathrm{n}$ measurement, in physics education, and physics practitioners. The valid instrument was tried to students in ten Islamic higher education institutes in Yogyakarta. Polychromous data were analyzed using Partial Credit Model (PCM) analysis. The result showed that there were 44 items that were compatible with PCM, so the PhysTHOTS instrument was proved to be compatible with PCM; with the reliability of .95; difficulty index was between -.86 and 1.06 which indicated all items in good category. Thus, PhysTHOTS had met the requirement to measure the higher education Physics students' higher-order thinking skills.

Based on the problems aforementioned, the education quality in Indonesia still needs improvements, including the teachers' competence to construct instruments that can measure HOTS. The first step should be taken is to reveal the problems faced by teachers in constructing high-order thinking instruments. The second step is to illustrate the teacher competence in developing high-order thinking instruments.

In the 2013 curriculum, teachers need to possess higher-order thinking abilities. Students need to acquire low-order thinking skills (LOTS) before mastering higher-order thinking skills (HOTS). LOTS are skills to remember, understand and apply the formula or the law. On the other hand, HOTS are skills more than remembering, understanding and implementing (Rosnawati, 2005; Trilling \& Fadel, 2009; Yee, Yunos, Othman, Hassan, \& Mohamad, 2015).

Based on the background, the purpose of this study were as followed: (1) to describe the Economics teachers' competence in constructing instruments to measure high-order thinking skills; (2) to describe difficulties Economic teachers' to construct high-order thinking instrument.

\section{METHODS}

This study employed quantitative method by using survey to describe Economics teachers' competence and to describe the problems and difficulties in developing the instruments for measuring higher-order thinking skills. The research subjects were Economics teachers and students at a state senior high school in Bandung which had implemented curriculum 2013. There were 45 teachers and 270 students from 27 state senior high school in Bandung.

The data were collected through documentation, questionnaires and focus group discussion (FGD). The documents were the questions made by Economics teachers in daily quizzes, mid-term exam, and final exam. The questionnaire was intended to acquire data related to teachers' difficulties in constructing instruments to measure high-order thinking skills in the form of multiple choices and openended questions. Moreover, a questionnaire was used to find students' perception on teachermade questions. Focus group Discussion (FGD) was utilized to draw the qualitative data related to teachers' problems and difficulties in giving high-order thinking instruction. This was conducted to match the obtained data from the questionnaire.

To validate the questionnaire, a construct validity test was carried out which include the layout, the formulation of indicators and question items. This was done to both questionnaires for teachers and students. Moreover, a documentation guideline was made according to the required data for documentation data collection.

The data analysis techniques used were descriptive statistics and qualitative analysis. Descriptive statistics was utilized to describe the data obtained from teachers and students in the form of frequency distribution tables. The collection data procedure is presented in Figure 1. 

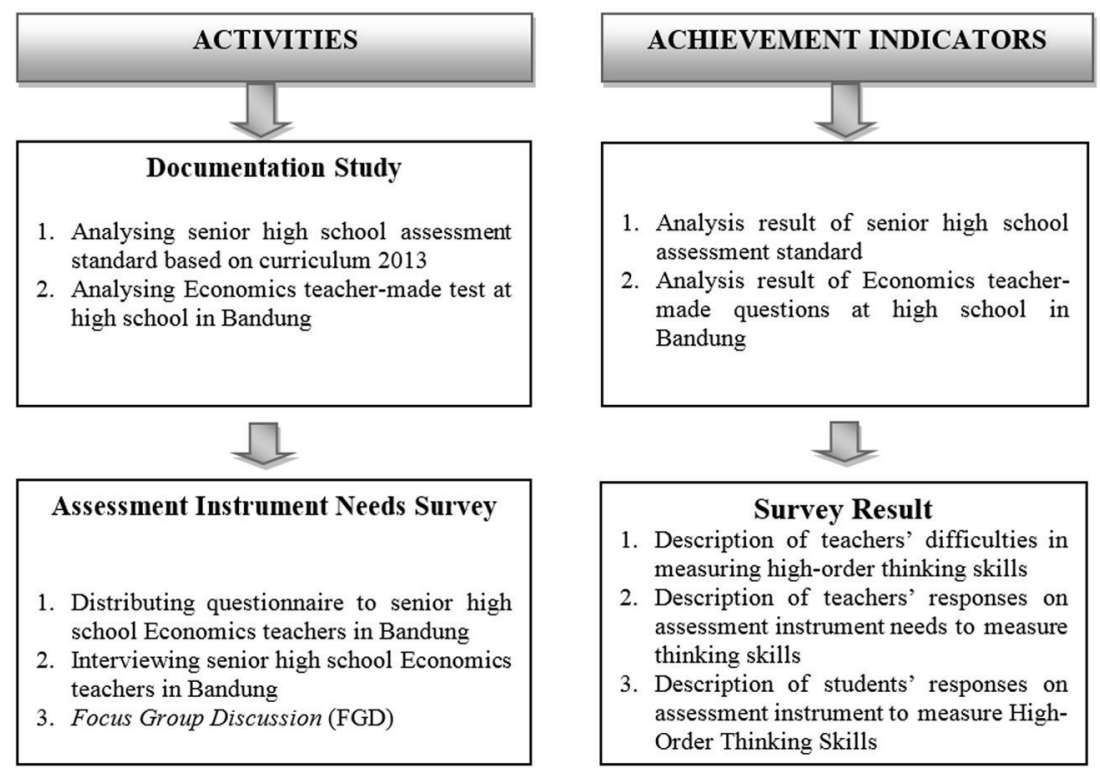

Figure 1. The Data Collection Procedure

\section{FINDINGS AND DISCUSSION Findings}

The result of the teacher-made questions analysis showed that teachers'skill in constructing questions at cognitive level was still low. The result implied that only $12 \%$ of the teachersmade questions that were at analyzing to creating level, while the other $88 \%$ were at remembering to applying level. This finding reflected teachers' lack of competency in constructing higher-order thinking questions. The teachers' insufficient competence in constructing questions was not only in cognitive skill but also in drafting contextual problem instruments drafting. Based on the document analysis, $10 \%$ of the questions were categorized as contextual-based problems.

As a consequence of teachers' low competence in learning assessment aspect, Economics teachers had difficulties in developing assessment instruments to measure high-order thinking skills (HOTS).

\section{The Description of Teachers' Difficulties in Constructing Instrument to Measure High- Order Thinking Skills (HOTS)}

In general, Economics teachers were aware that higher-order thinking skill is one of curriculum 2013 demands. Their knowledge in this issue was categorized sufficient. It can be seen from the data presented in Table 1.
Table 1. Teachers' Responses towards HighOrder Thinking Skills (HOTS)

\begin{tabular}{lcc}
\hline Statements & Frequency & $\mathbf{\%}$ \\
\hline $\begin{array}{l}\text { Understanding, mastering, } \\
\text { implementing }\end{array}$ & 2 & 3 \\
$\begin{array}{l}\text { Remembering, understanding, } \\
\text { implementing }\end{array}$ & 0 & 0 \\
$\begin{array}{l}\text { Analyzing, evaluating, creating } \\
\text { Critical Thinking and } \\
\text { troubleshooting }\end{array}$ & 40 & 57 \\
\hline
\end{tabular}

It can be interpreted that $97 \%$ teachers know that high-order cognitive abilities include the ability to analyze, evaluate, create, solve problem, and be critical thinking. Moreover, there were only $3 \%$ of the teachers answered the ability to understand, master, and implement.

Economic teachers' difficulties in constructing questions to measure high-order thinking skills aroused when teachers faced difficulties in formulating the indicators of basic competencies. The detailed data were presented in Table 2.

Table 2. Teachers' Responses in Formulating Indicators of Basic Competencies

\begin{tabular}{lcc}
\hline Statements & Frequency & $\mathbf{\%}$ \\
\hline $\begin{array}{l}\text { Do not face any difficulty in } \\
\text { formulating indicators }\end{array}$ & 13 & 29 \\
$\begin{array}{l}\text { Yes, I face difficulties in } \\
\text { formulating indicators }\end{array}$ & 32 & 71 \\
\hline
\end{tabular}


It can be inferred that $71 \%$ of teachers faced difficulties in formulating indicators, which include achievement and questions indicators. Only $29 \%$ of teachers did not have difficulies in the formulation indicators. In relation to highorder thinking skills indicators formulation, $80 \%$ of the teachers expressed their difficulties. The data were presented in Table 3.

Table 3. Teacher's Difficulties in Formulating Indicators

\begin{tabular}{lcc}
\hline Statements & Frequency & \% \\
\hline $\begin{array}{l}\text { Difficulty in selecting operational } \\
\text { verb which correspond to the }\end{array}$ & 9 & 20 \\
basic competence & & \\
$\begin{array}{l}\text { Difficulty in formulating } \\
\text { indicators to measure high-order }\end{array}$ & 38 & 80 \\
thinking skills & & \\
\hline
\end{tabular}

The difficulties faced by Economics teachers in formulating indicators become an obstacle in creating blueprint. The data presented in Table 4 provided information that only $20 \%$ of the teachers responded often, $62 \%$ teachers answered sometimes, and $18 \%$ said never create HOTS blueprint.

Table 4. Teachers' Responses on Creating HOTS Blueprint

\begin{tabular}{lcc}
\hline Statements & Frequency & $\mathbf{\%}$ \\
\hline Often & 9 & 20 \\
Sometimes & 28 & 62 \\
Never & 8 & 18 \\
\hline
\end{tabular}

There were several reasons why Economics teachers never create HOTS blueprint. The reasons were presented in Table 5.

Table 5. Teachers' Reasons of Not Creating HOTS Blueprint

\begin{tabular}{lcc}
\hline Statements & Frequency & $\mathbf{\%}$ \\
\hline $\begin{array}{l}\text { Do not know the blueprint } \\
\text { format which provide HOTS }\end{array}$ & 9 & 20 \\
$\begin{array}{l}\text { Face difficulty in formulating } \\
\text { HOTS questions }\end{array}$ & 21 & 47 \\
$\begin{array}{l}\text { Have insufficient understanding } \\
\text { on the relation between } \\
\text { blueprint and question items }\end{array}$ & 1 & 2 \\
Do not answer & & \\
\hline
\end{tabular}

It shown that $47 \%$ of the teachers still faced difficulty to formulate HOTS questions, $20 \%$ of teachers did not know the blueprint format which provide HOTS and Only $2 \%$ of the teachers had sufficient understanding on the relation between blueprint and questions items.

The difficulties faced by Economics teachers was not only in creating the blueprint, but also in constructing question items, both multiple choices and essay questions. The description of teachers' difficulties in constructing essay questions were presented in Table 6.

Table 6. Teachers' ${ }^{6}$ Difficulties in Constructing Essay Questions to Measure HOTS

\begin{tabular}{lcc}
\hline Statements & Frequency & $\mathbf{\%}$ \\
\hline $\begin{array}{l}\text { Difficulty in choosing the diction } \\
\text { to measure HOTS }\end{array}$ & 21 & 38 \\
$\begin{array}{l}\text { Difficulty in drafting question to } \\
\text { measure HOTS }\end{array}$ & 34 & 62 \\
\hline
\end{tabular}

It shown that $68 \%$ of the teachers expressed difficulty in formulating questions to measure high-order thinking skills, and $38 \%$ of the teachers struggled to decide the diction measure high-order thinking skills.

The Data of Economic teachers ' difficulties in formulating multiple choices questions is presented in Table 7.

\section{Table 7. Teachers' Difficulties in Formulating Multiple Choices Questions to Measure HOTS}

\begin{tabular}{lcc}
\hline Statements & Frequency & $\mathbf{\%}$ \\
\hline Formulating the stem & 17 & 23 \\
$\begin{array}{l}\text { Formulating a distractor } \\
\text { similar to the answer key }\end{array}$ & 25 & 35 \\
$\begin{array}{l}\text { Formulating problems that } \\
\text { measure HOTS aspect based } \\
\text { on the indicators }\end{array}$ & 30 & 42 \\
\hline
\end{tabular}

Based on the data in Table $7,42 \%$ of the teachers expressed the difficulty in formulating problems that measure HOTS aspect based on the indicators, $35 \%$ of the teachers faced the obstacle in formulating a distractor similar to the answer key, and $23 \%$ of the teachers faced difficulty in formulating the stem.

The teachers' difficulties were not only in constructing written tests (essay and multiple choices test) but also in constructing questions for oral tests, and to interact throughout the learning process to stimulate students' highorder thinking skills. The data on teachers' difficulties in formulating oral tests were presented in Table 8 . 
Table 8. Teachers ${ }^{6}$ Difficulties in Formulating Oral Questions That Stimulate Students' HOTS

\begin{tabular}{lcc}
\hline Statements & Frequency & $\mathbf{\%}$ \\
\hline Formulating the question & 35 & 67 \\
$\begin{array}{l}\text { Insufficient understanding } \\
\text { of the rules in formulating } \\
\text { question }\end{array}$ & 17 & 33 \\
\hline
\end{tabular}

It can be inferred that $67 \%$ of the teachers expressed difficulty in formulating oral questions to measure the high-order thinking skills, and $33 \%$ of the teachers were lack of understanding to formulate verbal questions to stimulate students' high-order thinking skills.

\section{Students' Response towards The Assessment Instrument to Measure High-Order Thinking Skills}

Based on the data analysis from the questionnaire, $53 \%$ of the students stated that they like and the rest of the students did not like the instrument. Furthermore, $75 \%$ of the students chose essay questions, $15 \%$ others chose multiple choice, $5 \%$ of the students chose matching, and the rest or $5 \%$ of the students chose short answer questions towards the kinds of test that can enhance higher-order thinking skills.

Student responses towards the questions frequently asked by teachers in the learning process indicated that $51 \%$ of the students stated that teachers used the word "mention" $11 \%$ were found out to use of word "explain", $15 \%$ utilized "what" question, 7\% employed "why" question, and $7 \%$ used "how".

Moreover, students' responses toward questions that appeared in the post-test illustrated that $59 \%$ of the students stated that the teacher used the word "mention" for $11 \%$, "what" for $4 \%$, "explain" for $22 \%$, "why" for $4 \%$; and "how" for $4 \%$.

\section{Discussion}

The analysis result of the teacher-made questions showed that the teachers' skills in making cognitive level questions were still low. The result indicated that $12 \%$ of the teachermade questions were in analyzing to creating level, while the other $88 \%$ of the questions were at remembering to applying level. This finding reflected the teacher' lack competence in formulating higher-order thinking skills questions. Moreover, the teachers were also found out to be insufficient in drafting instruments (making questions) based on contextual problems. Referring to the document analysis, only $10 \%$ of the questions were categorized as contextual-based problems.

As the consequence of the teachers' low competence in learning assessment, Economics teachers needed to struggle in developing assessment instruments to measure high-order thinking skills (HOTS). The result indicated that $80 \%$ of the teachers faced difficulty in formulating higher-order thinking skills indicators. Therefore, $47 \%$ of the teachers had difficulty to arrange the problems or questions to measure the high-order thinking skills. Only $20 \%$ of the teachers were accustomed to develop blueprint to measure high-order thinking skills. The difficulties did not come up only in planning (developing the blueprint) but also in formulating instruments both in essay questions and multiple choices questions.

For the essay questions, $68 \%$ of the teachers stated that it was difficult to make questions to measure the high-order thinking skills, and $38 \%$ of the teachers struggled to choose the appropriate diction to measure high-order thinking skills. Furthermore, $35 \%$ of the teachers faced difficulty in formulating the distractor which is quite similar to the answer key, and 23\% of the teachers tried hard to formulate the stem. The qualitative data revealed from the Focus Group Discussion (FGD) provided information that Economics teachers were still struggling to develop qualified multiple choices and essay items. In formulating essay questions, it is difficult to formulate problems which intended to develop critical thinking skills as an aspect of high-order thinking skills (HOTS). On the other hand, the difficulty in making multiple choices was in creating the distractor. The FGD result also indicated the instrument models needed to develop HOTS based instrument.

Teachers' difficulties were not only in drafting written tests, but also in formulating oral questions for oral exam and for interacting in the learning process. A total of $67 \%$ of the teachers expressed their difficulty in formulating verbal questions to measure high-order thinking skills, and $33 \%$ of the teachers were lack of the instruction to formulate oral questions to 
stimulate student higher-order thinking skills.

The findings aforementioned were in line with the data obtained from students' questionnaire. According to students, the teachermade questions for the exam and during the learning process were dominated by questions to measure low-order thinking skills (LOTS) such as "explain" and "mention". In addition, only $4 \%$ of the questions used "why" and 4\% used "how". Both of the question types can be used to measure higher-order thinking skills (HOTS). Moreover, students expected the teachers to (1) make questions that emphasize understanding skill, not remembering; (2) provide the expected answer not textbook oriented; (3) make problems in applying level; (4) give interesting and innovative test questions; (5) make questions for thinking practice; and (6) guide the students to think in high-order levels.

The teacher-made questions during the learning and in the written tests were still dominated by low-order thinking skills questions such as using "what" and "mention" questions. In addition, there were questions to measure higher-order thinking skills such as using "explain". According to students, only $4 \%$ of the questions utilized "why" and $4 \%$ used "how" appeared in the written tests made by the teachers. Both types of question could measure high-order thinking skills (HOTS). Students also expected teachers to (1) make questions that emphasize understanding skill, not remembering; (2) provide the expected answer not textbook oriented; (3) make problems in applying level; (4) give interesting and innovative test questions; (5) make questions for thinking practice; and (6) guide the students to think in high-order levels.

Related to the teachers' competence in drafting insufficient HOTS questions, this is in line with the Nurhayati (2011) reported that the teacher-made questions had not measured the high-order thinking skills. Similarly, a study conducted by Syahida \& Irwandi (1983) revealed that the questions in the national exam had not measured higher-order thinking skills.

The instruments to measure the higherorder thinking skills should have characteristics that fit their goals. The characteristics of highorder thinking skills according to Christopher, Thomas, \& Tallent-Runnels (2004); Arends (2013) are (1) thinking in non-logarithm, which means that action cannot be directed from the beginning; (2) complex. The overall direction is not "visible" from one point of view; (3) higherorder thinking often resulted on multi-solutions, each with its consequence and benefit, and not a unique solution; (4) it involves judgment and interpretation; (5) it involves multi-criterion implementation which sometimes contradicted; (6) it often involves uncertainty. Moreover, not everything in the task is familiar; (7) high order-thinking involves self-thinking. In higherorder thinking, there is no clue given by others; (8) high-order thinking can involve meaning enforcement, discovering structures in clear deviations; and (9) high-order thinking is full of effort. There is a great mental work involved in elaboration and assessment required.

Referred to the Pedagogical Content Knowledge (PCK) concept by Shulman (1987), the above findings indicated that the Economics teacher assessment knowledge to develop instruments to measure high-order thinking skills (HOTS) is relatively low. However, assessment knowledge is one of the important elements of PCK that must be acquired by Economics teachers. Therefore, there must be an effort from various parties related to teacher competence improvement to facilitate education and training programs in improving teachers' ability to construct higher-order thinking skills instruments.

\section{CONCLUSION}

Teachers' competence in formulating cognitive level questions is still considered low. The result showed that only $12 \%$ of the teachermade questions were in analyzing to creating level, while other $88 \%$ of the questions were remembering to applying level. Therefore, the Economics teachers had difficulties in developing assessment instruments to measure high-order thinking skills (HOTS). The difficulties were from formulating the blueprint to develop the instruments in the form of tests. Based on the competence and difficulties in developing the instrument, Economics teachers need guiding instruction to formulate blueprints, develop questions for both essay and multiple choices tests. In addition, teachers also need intensive training on developing instruments to measure HOTS. 


\section{ACKNOWLEDGEMENT}

We would like to express our gratitude to all Economics teachers and students in Bandung who involved in this study. In addition, our extended appreciation goes to Directorate of Research and Community Service, the General Directorate of Research and Technology Reinforcement of the Ministry of Research, Technology, and Higher Education that financially support this study through National Institution Strategic Research.

\section{REFERENCES}

Arends, R. I. (2013). Learning to teach. Yogyakarta: Pustaka Pelajar.

Biggs, J. (1996). Enhancing teaching through constructive alignment. Higher Education, 32(3), 347-364. doi:10.1007/bf00138871.

Christopher, M. M., Thomas, J. A., \& Tallent-Runnels, M. K. (2004). Raising the bar: Encouraging high level thinking in online discussion forums. Roeper Review, 26(3), 166-171. doi:10.1080/02783190409554262.

Danarwati, Y. S. (2016). Manajemen pembelajaran dalam upaya meningkatkan mutu pendidikan. [Learning management in an effort to improve the quality of education]. Jurnal Mimbar Bumi Bengawan, 6(13, 1-18. http://stiaasmisolo.ac.id/jurnal/index.php/jmbb/ article/view/21.

Depdiknas RI 2014. Panduan penulisan butir soal. [Guide to writing questions].

Fahmi, C. N., Murniati, A. R., Nurliza, E., \& Usman, N. (2019). The implementation of academic supervision in improving teacher competency at primary school. Jurnal Ilmiah Peuradeun, 7(1), 181-194, doi:10.26811/peuradeun.v7i1.202.

Gall, M. D., Gall, J. P., \& Borg, W. R. (2003). Educational research: An introduction $\left(7^{\text {th }}\right.$ ed). Boston, MA: Pearson Education, Inc.
Haynie, W. J. (1992). Post hoc analysis of test items written by technology education teachers. Journal of Technology Education, 4(1), 26-38. doi:10.21061/jte. v4i1.a.3.

Istiyono, E., Mardapi, D., \& Suparno, S. (2014). Pengembangan tes kemampuan berpikir tingkat tinggi fisika (PhysTHOTS) peserta didik SMA. [Development of high-level thinking skills tests in physics (PhysTHOTS) of high school students]. Jurnal Penelitian dan Evaluasi Pendidikan, 18(1), 1-12. doi:10.21831/ pep.v18i1.2120.

Mullis, I. V. S., Martin, M. O., Foy, P., \& Arora, A. (2012). TIMSS 2011 international results in mathematics. Massachusetts: TIMSS \& PIRLS International Study Center.

Nagappan, R. (2001). Language teaching and the enhancement of higher-order thinking skills. Anthology series-seameo regional language centre, 190-223.

Nagro, S. A., Fraser, D. W., \& Hooks, S. D. (2018). Lesson planning with engagement in mind: proactive classroom management strategies for curriculum instruction. Intervention in School and Clinic, 54(3), 1-10. doi:10.1177/1053451218767905.

Nesbitt-Hawes, P. J. (2005). Higher order thinking skills in a science classroom computer simulation. (Master's Thesis, Queensland University of Technology Brisbane). https://eprints.qut.edu. $\mathrm{au} / 16201 /$.

Rosenshine,B., Meister,C.,\&Chapman,S.(1996). Teaching students to generate questions: A review of the intervention studies. Review of Educational Research, 66(2), 181-221. doi:10.3102/00346543066002181.

Rosnawati, R. (2005). Pembelajaran matematika yang mengembangkan berpikir tingkat tinggi. [Mathematics learning that 
develops high-level thinking]. Paper presented at Seminar Nasional.

Shulman, L. S. (1987). Knowledge and teaching: Foundation of the new reform. Harvard Educational Review, 57(1), 1-22.

Syahida, A., \& Irwandi, D. (2015). Analisis keterampilan berpikir tingkat tinggi pada soal ujian nasional kimia. [Analysis of high-level thinking skills on the national chemistry exam questions]. Jurnal Edusains, 7(1), 77-87. doi:10.15408/ es.v7i1.1404.

Thompson, T. (2008). Mathematics teachers' interpretation of higherorder thinking in Bloom's Taxonomy. International Electronic Journal of Mathematics Education, 3(2), 96-109. doi:10.1.1.153.1356.
Trilling, B., \& Fadel, C. (2009). 21st century skills: Learning for life in our times. John Wiley \& Sons.

Vui, T. (2001). Practice trends and issues in the teaching anf learning of mathematics in the countries. Penang: Recsam.

Winne, P. H. (1979). Experiments relating teachers' use of higher cognitive questions to student achievement. Review of Educational Research, 49(1), 13-49. doi:10.3102/00346543049001013.

Yee, M. H., Yunos, J. M., Othman, W., Hassan, R., Tee, T. K., \& Mohamad, M. M. (2015). Disparity of learning styles and higher order thinking skills among technical students. Procedia-Social and Behavioral Sciences, 204(2015), 143-152. doi:10.1016/j.sbspro.2015.08.127. 